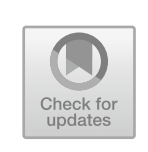

\title{
The Life of Breath: Contexts and Approaches
}

\author{
David Fuller, Jane Macnaughton, and Corinne Saunders
}

\section{Contexts and Approaches: 'The Age of the Breath'?}

'The Age of the Breath': in the view of the philosopher Luce Irigaray, this characterises the late twentieth century and beyond. ${ }^{1}$ Irigaray's idea is a variation of the threefold scheme of Christian history of the medieval theologian Joachim da Fiore: the Age of the Father (the Old Testament, the Law), the Age of the Son (the New Testament, freedom from the Law), and the Age of the Spirit (a utopian age of universal love). Like the Age of the Spirit, Irigaray's 'Age of the Breath' potentially transcends major limitations of history, specifically on issues of gender and all that follows from differently conceived relations between men and women. Breath is central to this in her reworking of a major philosophical predecessor, Martin Heidegger. ${ }^{2}$ Heidegger is admired: he thought radically, working not only from what had already been thought but attempting to see nakedly from the bases of thinking. Irigaray's critique is not of Heidegger himself, but of Heidegger as representative of even the best in the tradition of Western philosophy, limited by its unrecognised assumption of the thinking subject as male. For Heidegger the primary element is earth-solid, and for Irigaray, masculine. For Irigaray more primary,

D. Fuller $(\bowtie) \cdot$ J. Macnaughton · C. Saunders

University of Durham, Durham, UK

(C) The Author(s) 2021

D. Fuller et al. (eds.), The Life of Breath in Literature, Culture

and Medicine, Palgrave Studies in Literature, Science and Medicine, https://doi.org/10.1007/978-3-030-74443-4_1 
more utterly essential to Being, is the element of air-fluid, and feminine; the basis of life, the substance of the breath.

One need not accept Irigaray's arguments about gender to see the interest of her claim and the fecundity of its ramifications. ${ }^{3}$ Breathing can be recognised (often elicited in retrospective analysis) as a major issue in many areas of twentieth- and twenty-first-century thinking: in philosophy, in feminism, in the arts, in psychoanalysis, in education, in religion, in politics, and in cultural geography, especially ecological issues including the contemporary global problems of air pollution and climate change. As with other conditions of life so axiomatic that attention has often scarcely been paid to them, recent writing in many areas, by bringing breath more into view, opens up a wide variety of new perspectives. In the current context of a global breathing-illness pandemic, COVID-19, with all that has exposed about global health issues and national and international relations, and with myriad implications as yet far from fully recognised, it can hardly be contested that Irigaray's characterisation of the late twentieth and early twenty-first centuries has been prescient.

Many areas of thought elicit a related sense of the period, sometimes from quite different starting points. In philosophy, Peter Sloterdijk's Terror from the Air argues that the use of poison gas in World War I was a fundamental reorientation of warfare, attacking not the enemy's body but the enemy's breathing environment. Extended in other terrors of atmospheric violence, from the gas chambers of the extermination camps of World War II to recent attempts to control the weather for military purposes, this has brought the relation of human beings to the atmosphere on which life depends, formerly taken for granted, newly into consciousness. It has also generated a new counter-awareness of the need for atmospheric hygiene and techniques for monitoring and maintaining air quality. ${ }^{4}$ The issue of poison gas is only one element in Sloterdijk's argument. He presents the twentieth century as an 'age of explication', meaning that many aspects of existence formerly tacit are brought to more conscious notice and newly explored. As with Irigaray, a central focus is air and breathing, though brought to attention by a quite different route. ${ }^{5}$

Sloterdijk's extension of his argument to include the arts, with Surrealism seen as initiating modes of art as 'atmo-terrorism' designed to attack audiences, has proved less persuasive than his central thesis, and can be detached from his fundamental claim about an age of explication. With the arts Sloterdijk's thesis might more convincingly be extended to the theatre, to the twentieth century's revival of theatrical traditions 
less verbal, less cerebral, most obviously in the misleadingly named 'theatre of cruelty' of Antonin Artaud, in which the issue is not cruelty in any ordinary sense but the visceral nature of fully theatrical experience. It is a mode of theatre in which text is recognised as only one element, with movement, dance, costume, setting, lighting, but above all the body of the actor in all the viscerality of its emotional experience: the blood, the breath. The total art work with its address to the whole mind-body; but activated not with the familiar defamiliarisation of Brecht, addressing the detached intellect, but with what is permanently unfamiliar to the composed social being: myth, by which, 'using breathing's hieroglyphics', the audience is assaulted, disconcerted, disturbed, as by anxiety, fear, the erotic. ${ }^{6}$ Artaud's ideal is more truly an aesthetic 'atmo-terrorism' than Sloterdijk's Surrealism. ${ }^{7}$

Sloterdijk's 'age of explication' thesis might more comprehensively be extended not to what the arts are in the twentieth century and beyond but how they are understood, with explication-an ever-increasing sophistication of consciously-applied critical techniques-replacing education through practice (the teaching of rhetoric, drawing, musical performance), with its concomitant address to cultivated intuition. Nevertheless, twentieth-century art has thematised breathing, most famously in Samuel Beckett's textless playlet-cum-happening, Breath, written originally (with Beckettian humour) for Kenneth Tynan's erotic review, Ob! Calcutta! (1969). A recent study has shown the resonance of Beckett's birth-cry to death-rattle encapsulation in a range of creative work before and after Beckett, including ways in which breathing can be presented in new modes of visual art (often with associated new problems for art criticism about the very nature of art), from happenings, performance-art, and anti-art to conceptual art and work in more traditional modes. ${ }^{8}$

Breathing can also be seen as foregrounded in relation to Lacanian psychoanalysis, drawing on Lacan's seminars on anxiety of 1962-1963. ${ }^{9}$ The fundamental idea of this series is that the object of anxiety is not known: anxiety is fear without focus. Lacan calls the hidden provocation 'object (petit) a' (autre/other). While the syndrome comes into being through post-Freudian Lacanian norms (primary deprivations of desire) which to the non-believer may sound unpersuasive if not fantastical, the syndrome itself-fear without focus, dependent on desire concealed by displacement-may be recognised outside specifically Lacanian frameworks of origin. Given the obvious relation of anxiety to breathing (constricted breathing, suffocation, as symptom or effect) it is surprising 
that Lacan himself has so little to say about breath-little more than a brief serio-comic episode on the conception of Christ by the entry of the breath of the Holy Spirit (spiritus of the Sanctus Spiritus) through the Virgin's ear, in which he relates the (divine) mouth to other orifices and the (divine) breath to other excretions. ${ }^{10}$

In Staying Alive Aranye Fradenburg includes an extended discussion of Lacan on anxiety which suggests what he might have said about breath. ${ }^{11}$ A passionately-written anti-utilitarian defence of the arts as fundamental to the possibilities of humane living, the book is also a deeply well-informed critique of the contemporary university as semi-automated learning-factory, in which the aim is not knowledge and understanding but certification as a passport to employment. Exchange between intellectuals (albeit a great deal of what passes for this in universities is a parody of the real thing), real exchange, models a humane community. This is reflected in the organisation of Staying Alive, in which Fradenburg is in dialogue with an interactive counterpoint of related views ('fugues'). It is a mode that conveys a human presence relating felt thought to the subtle, mysterious, even bizarre - those aspects of human experience to which the arts are addressed, which are antithetical to the antiseptic of institutional bureaucracy.

In the chapter specifically concerned with Lacan and breathing, Fradenburg takes the highly interpretable objet a to be a 'conceptualization of the embodied mind's experience of change' (Staying Alive, 164), an index therefore of the crucial presence of the body in intellectual activities, which are often (wrongly) understood as not shaped by their basis in corporeality. As the primary experience of change, respiration, suddenly independent at the trauma of birth (thrust from a protected to a vulnerable condition-to anxiety), helps us to think, she argues, about the psychosomatic nature of rhetorical structures - the not unusual modern argument that writing is from the body, which when (as here) performed as well as affirmed requires an active and sympathetic reader. In Ruth Evans' response objet $a$, as reconceived by Fradenburg, becomes breath as a catalyst that sets off love: respiratory shapes in literary language (Frank O'Hara, Margery Kempe) brought off the page by real interaction with a responsive reader; breath heard and seen in the work of performanceartists (the duo, Smith/Stewart). Evans exemplifies the claim made from various perspectives by the whole book: the arts (and not the arts alone, but the arts understood in relation to contemporary conceptions of the 
life sciences as comparably interpretable), the arts are as necessary to living as breath.

One aspect of the fundamental issue Fradenburg addresses-'staying alive' in an academic context-involves escaping norms of academic 'professionalism' which encourage people to act as semi-automata, minds without bodies, not as human beings emotionally as well as intellectually responsive to interpretive complexity. In the liberal arts some traditions of criticism connecting literary study with life values and experience continue to recognise interactions between culturally situated and individually idiosyncratic readers from whom art requires active, engaged responses. In academic contexts, however, these have often been displaced by a pseudo-science of scholarship designed to demonstrate supposed objective presence (in a text, in a context) analogous, as Fradenburg argues, to a superseded notion of 'hard' science. Fradenburg aims to reverse this dehumanising process, which funding difficulties created by the COVID19 pandemic have now newly intensified in universities worldwide. As institutions seek to fund their activities by moves to online learning that do away with people meeting together physically, with all the interpretable signals of actual life such meetings entail, and replace these with virtual meetings significantly evacuated of human presence-the living, breathing, emotionally-signalling body - the breathing illness potentially contributes several turns of the screw to intellectual-emotional suffocation. But, like properly holistic medicine, teaching in the Arts and Humanities must engage, Fradenburg argues, with the embodied mind.

Philosophy, feminism, the arts, psychoanalysis, structures and practices of higher education: and the editors of a recent collection on air and breathing offer re-orientations in yet more directions. ${ }^{12}$ Like Irigaray, they begin from a critique of Western philosophy (tendentiously exemplified by a reading of a famous passage of Descartes), though they also acknowledge predecessors in Western tradition: apart from Irigaray, Gaston Bachelard, Elias Canetti, Merleau-Ponty and Levinas. The collection draws positively too on the place of disciplines of breathing in ancient Chinese philosophy (the Daoist philosopher traditionally known as Chuang Tzu, now Zhuang Zhou), modern Sufism (the Sufi master, Inayat Khan), and (again like Irigaray) in Eastern religious and spiritual traditions. From this they propose a 'respiratory philosophy' based in more conscious attention to and practice of breathing. If their critique of the Western philosophical tradition seems less substantial than Irigaray's this is in part because it is simpler. Whereas Irigaray grapples-tentatively, 
speculatively - with a profound problem of ontological consciousness in Heidegger, they convict Descartes of straightforward error: his supposed new beginning ignores his breathing. Descartes, one imagines, would have thought this critique readily answered: the observation is correct, but has no bearing on his reorientation of thinking. Descartes' writings began a new phase of Western philosophy not because he, and the most powerful minds of succeeding centuries, failed to identify this supposed omission, but because of his work's genuine and powerful originality. (Irigaray's new beginning is quite different: fundamentally she agrees with Heidegger about the aims and methods of philosophy, but plausiblylike Heidegger himself-looks to a new place for a first ground. The questioning, tentative and often syntactically inconclusive openness of her critique also recognises - as did Heidegger — that a new mode of thinking requires new modes of expression.)

That the critique of Descartes is tendentious does not, however, impugn the renewed and new attention to breathing drawn from it, the validity of which can be best considered in terms of its results. Much of the new reading in the collection is concerned with issues and figures in Western culture examined afresh in relation to theories and practices that variously foreground breathing from a range of Eastern traditions. The stress on practice is recurrent. The new philosophy is a new way of being: not on our lips only but in our lives also. This is exemplified by a discussion of Derrida's exploration of breath in Artaud, background to a new way of performing philosophy: in their different spheres both Artaud and Derrida match new ideas with new modes of expression. ${ }^{13}$ Similarly with a phenomenology of breathing illnesses: it requires a new imagination of mind-body integration; a holistic understanding of the subjective experience of illness complementary to objective clinical analysis, treating the whole person in his or her context. ${ }^{14}$

The collection as a whole, like Sloterdijk's Terror from the Air, and much other recent writing on breath, breathing and breathlessness, recognises ramifications that are international and urgently relevant, as indexed by the relatively new focus of the World Health Organisation on air quality (http://www.who.int/airpollution/en/). As well as involving elements of individual choice - the choice to evolve and exercise a 'respiratory philosophy'-there is a larger sense in which 'atmospheres of breathing' affect health issues with the widest social ramifications. Choice can be exercised about these only by international political co-operation, and through negotiations in which the principal sufferers are often those 
with least political and economic power. Nevertheless, understanding that air pollution is a major cause of poor health-not only of breathing illnesses directly but also of heart disease and strokes-underlies efforts to clean up the polluted cities of developing industrial economies. Along with its consequences in climate change it also underlies the drive for clean air legislation in many parts of the world, with its potentially radical consequences for how we all live.

A comparably international perspective on the twentieth century and beyond as an 'age of the breath' in religion has two prominent and very different strands: Christian Pentecostalism, emphasising direct personal experience of God through baptism by the descent of the Holy Spirit, the breath of God; and the discovery in the West of ancient practices derived from the Sütras of Patañjali (ca. $400 \mathrm{BCE}$ to $400 \mathrm{CE}$ ), texts connected with Hinduism, Buddhism, and Jainism, concerned with disciplines of breathing in relation to spiritual awareness. ${ }^{15}$ In the second of these areas Irigaray is again a significant figure, though interest in the Sutras in European culture dates from earlier, one of the most prominent early translators, Charles Johnston, being a member of the late nineteenthcentury literary and theosophical circle which included the poet W. B. Yeats.

Irigaray's Between East and West presents the issue of learning new practices of breathing as fundamental to a positive redirection of consciousness. ${ }^{16}$ Only through this new practice, bringing into being a new relation of the mind to the body, Irigaray argues, is it possible to move beyond what she presents as the destructive elements of Western metaphysics and the spiritually empty (male) struggle to dominate nature: its aim is a new relation between the sexes, new possibilities of community, and the coexistence of diverse communities required by contemporary societies. Irigaray's argument has the strength of her training in Western intellectual traditions and their modes of critique complemented by profound reorientation through her own lived and evolved knowledge of Indian spiritual practices. ${ }^{17}$ She writes, that is, from a complementary basis of intellectual analysis and whole-person experience. While Irigaray's specific arguments about gender and community are her own, her fundamental approach is congruent with a general tendency in contemporary Western societies, more than ever conscious of religious diversity and the cultural bases of belief, to value religion less in terms of faith and doctrine and more in terms of spiritual knowledge and practice. 
Pentecostalism is quite different-a version of an antithetical strand in contemporary religions, the return to renewed fundamentalisms, Christian, Muslim, and Hindu. The understanding of the Christian God as a triune figure, Father-Son-Spirit, means that breath, and the crucial multivalent terms-Hebrew ruach, Greek pneuma, Latin spiritus-have always been central to Christianity. ${ }^{18}$ Disciplines of breathing, though more prominent in Eastern religions, have also been present in many periods of the history of Christian prayer-in the prayers of medieval mystics ${ }^{19}$ in the practices of prayer proposed in the widely-distributed Spiritual Exercises (1541) of St Ignatius of Loyola, ${ }^{20}$ and in the methods recommended for saying the 'Jesus prayer' (sixth-century) from the quite different background of Eastern Orthodoxy. This became widely known in Western Christendom through the nineteenth-century compilation, The Way of the Pilgrim, ${ }^{21}$ which, after its translation in the 1930 s, became one of the most widely-circulated books about Christian practices of prayer, conveying something of its background in an eighteenth-century collection of fourth- to fifteenth-century texts, the Philokalia, the most significant and authoritative compilation in Orthodoxy after the Bible. Here too psychosomatic techniques of prayer, based on a view of the body as 'an essential aspect of total personhood', emphasise the importance of disciplines of breathing. ${ }^{22}$

Nevertheless, breathing disciplines are less evident in Christian practices of prayer and meditation than in those of Eastern religions. Even the visitation of the Holy Spirit, the breath of God, though important in the scriptural account of the accomplishment of Christ's mission of salvation (Resurrection, Ascension, Descent of the Spirit), became suddenly prominent in a new way in the early twentieth century. Now a worldwide church with an estimated 280 million adherents in Africa, India, the Americas, Europe, and Scandinavia, Pentecostalism takes its origin and much of its character from African American charismatics meeting in Los Angeles in 1906. Central to Pentecostal belief is baptism by the Holy Spirit, the breath of God, characteristic manifestations of which are the mutually-inspired in-and-out-breathings of congregational communities in whooping, shouting, laughing, singing, and speaking in tongues. It is a religion with political implications: unstructured forms of worship in which any member of a congregation can take the lead model nonhierarchical forms of society in the world beyond the church. One recent account of black Pentecostalism sees it as rejecting the whole of Western civilisation as fundamentally white supremacist and hetero-patriarchal, in 
its intellectual frameworks (philosophy, theology) as well as its social and political structures; its positive aim as to imagine 'otherwise' modalities and epistemologies, which connect the movement with whatever is broadly non-heteronormative and liberationist. ${ }^{23}$

Stressing embodied thinking, this account, though ostensibly a radical rejection of Western traditions, can, nevertheless, be seen as congruent with other contemporary critiques of dualist mind-body modes of thought. How difficult it is to think embodied experience, however, is strikingly demonstrated by the account's contrast between an experiential narrative of breathing and emotion in episodes from two Pentecostal sermons, incorporating community responses, and a 'scientific' version of the relationship between breathing and emotion. ${ }^{24}$ The two approaches are so radically different that the language of the scientific account positively excludes the mode of what is to be conveyed in the Pentecostal experience. The associated critique of major European and Scandinavian theologians of Pneumatology and the PentecostalCharismatic (Jürgen Moltmann, Veli-Matti Kärkäinen) - that they exclude black Pentecostalism because they are unable to deal with the physicality of its breathing - may be weakened by overworked invocations of 'otherwise' possibilities; but the book certainly succeeds in avoiding the all too usual intellectual's embarrassment about emotion and in illustrating the difficulties of intellectualising about bodily experience. As with Irigaray on Heidegger, as with Fradenburg on Lacan, as with Derrida's interaction with Artaud, it indicates the need for new modes of intellectual performance to match and engage with more embodied conceptions of intellectual experience.

As with breathing and air pollution, the issue is not only how to think but also how to live. Pentecostal practices of worship imply practices of social organisation, particularly because in its early twentieth-century beginnings the co-breathing of brothers and sisters in sharing the spirit recognised no racial limitations: black and white members of a congregation prayed together, contravening then current segregation laws in the southern states of the USA. Pentecostalism was therefore an early example of political movements in which breathing becomes a metaphor for freedom, constriction of breathing a metaphor for oppression.

'I can't breathe': the last words of Eric Garner, an African American who died as the result of a prohibited chokehold applied during arrest by police in New York in July 2014. 'I can't breathe': also the last words of George Floyd, an African American who died as the result 
of violent arrest by police in Minneapolis in May 2020. As a result of the death of George Floyd there were demonstrations against police brutality, and more generally against racial oppression, in every state of the USA, and internationally. 'I can't breathe': the words originally associated with protests against the killing of Eric Garner, after the death of George Floyd became the slogan-symbol of an international movement against racism and racial oppression, Black Lives Matter. ${ }^{25}$

Even before the death of George Floyd the wider political implications of the words had been developed by the political theorist, Achille Mbembe. $^{26}$ 'Caught in the stranglehold of injustice and inequality, much of humanity is threatened by a great chokehold' $(\$ 2)$ : in terms that refer back to the death of Eric Garner but are also prescient of the events that gave rise to Black Lives Matter, Mbembe interprets the international inequalities exposed by the COVID-19 pandemic as quasi-apocalyptic signs. Dehumanising digital communication; oppressive exploitation of postcolonial and developing communities; destructive exploitation of nature, all on an international scale: the political metaphors of oppression and the literal consequences of polluted environments point in the same direction. They are signs of the need to return to every living thing-human, plant, and animal - the space and conditions required for its breathing.

\section{The Life of Breath Project}

This book was inspired by the Life of Breath project (https://lifeofbreath. org/), a collaborative interdisciplinary study based at the Universities of Durham and Bristol, UK, and funded by the Wellcome Trust. The project has brought together researchers in arts and humanities, social science and clinical science, healthcare professionals, activists and also 'experts by experience'-those with personal experience of breathing-related diseases. It takes up the complex, mysterious yet crucial aspects of experience connected with breath and breathlessness. It speaks to the present as an 'age of breath'. At the same time it addresses the relative invisibility of breath within the medical community, the silences surrounding breathlessness and breathing illnesses, and the continuing need for language and ways of expressing breath and its lack-needs so powerfully evoked by thinkers and writers from the late twentieth century onwards.

The project was founded on the proposition that breathing and breathlessness can only be understood fully through the insights of cultural, 
historical, and phenomenological sources, and through incorporating perspectives derived from the arts and humanities into the clinical understanding of the physical symptom of breathlessness. By transforming understandings of breath and breathlessness the research aimed to reduce stigma and empower those who live with breathing illnesses. It also aimed to offer new possibilities for therapy and the management of diseases for which breathlessness is the primary symptom.

The integration of cultural and clinical understandings has been central to the Life of Breath as a 'critical medical humanities' project. While medical humanities was for many years associated with broadening the education of clinicians, in particular medical students, it is now recognised that the humanities also have a key role to play in influencing the evidence base for clinical interventions that goes far beyond enhancing the empathy of practitioners. 'Critical' medical humanities is characterised by interdisciplinarity, ensuring that knowledge and methods from arts and humanities as well as social sciences are mobilised to understand and address health problems in ways that are integrated with clinical knowledge. The force of 'critical' asserts the value of the humanities in calling attention to the richness and importance of the contexts in which lives are lived and illness experienced. ${ }^{27}$ The arts serve both to reflect and to illuminate experience: they play crucial roles in offering language and other forms of expression to articulate experience and frameworks for understanding.

The Life of Breath project took up the approach and methods of critical medical humanities to explore breath and breathlessness from an interdisciplinary perspective alongside the insights of those who live with breathlessness. ${ }^{28}$ One aim was to use the outcomes of research drawing on medical humanities perspectives to inform and improve clinical practice, expanding the evidence base, addressing the lack of knowledge surrounding the embodied experience of breathing and breathlessness, and exploring how this connects with cultural attitudes and assumptions concerning breath. Research strands spanned varying cultural conceptions of breath, the medical history of breathlessness, the development of a phenomenology of breathing, including through work with trained and aware or 'interesting' breathers (diving, exercising, singing, playing a wind instrument, and even sleeping), and the experience of clinical breathlessness, with a focus on the ways in which the clinical encounter shapes notions of breathlessness and the problems of 'symptom discordance', the 
mismatch between objective measurements of lung function and patients' experience of breathlessness.

Though common to many diseases, chronic breathlessness is most often caused by the condition known as chronic obstructive pulmonary disease (COPD), the third most common cause of death globally. ${ }^{29}$ In western countries, COPD is frequently caused by smoking, which is highly stigmatised. Physical constraints which are consequences of COPD are often compounded by shame, with the result that breathlessness sufferers hide away from society and may feel undeserving of help. ${ }^{30}$ Conditions causing chronic breathlessness are also typically associated with older age groups and with low socio-economic status. ${ }^{31}$ Partly because of this, research into respiratory diseases has had few energetic champions to redress the pressing need for improved funding and political action.

The COVID-19 pandemic has, however, brought breathlessness into sharp relief with peculiar global urgency. The Life of Breath project thus seems eerily prescient. In 2015 when the project began it was on the basis that breathing illnesses were relatively unnoticed and research into them was underfunded. In 2017 when the essays in this volume were commissioned, in 2018 when the contributors met together to hear and engage with each other's work, in 2019 when the essays were completed, that situation had not substantially changed. In 2020, as the editors worked on putting the volume finally together, and in 2021 , as the volume goes to press, the pandemic has transformed the world. A virus that literally takes away our breath has caused many thousands of deaths - at the time of writing (late February 2021) in the UK over 120,000 people, in the USA over 510,000, and globally over 2,520,000, with over 110 million cases confirmed worldwide. ${ }^{32}$ The illness has devastated the lives of individuals, families, and communities. Its as yet incalculable but evidently huge repercussions are a primary preoccupation of medical research, national governments, and international relations and organisations. Attempts to limit the spread of the virus have driven economies and businesses to ruin, and radically changed how we live, work, and relate to each other. Breath-and its lack-now seem more than ever to signal the ways in which human beings are united: every act of care taken not to spread the virus contributes to the common good, every act of carelessness to the common suffering. It has also shown how we are different. 'We're all in this together' has been a common statement of solidarity by politicians, but COVID-19 has emphasised that some are more vulnerable 
than others, in Europe and the USA especially Black, Asian, and minority ethnic communities. COVID-19 has underlined the key role of social deprivation in making people more vulnerable to ill health and shown that the poorest communities are often among those that have suffered the most. ${ }^{33}$ While 'conspiration', 'breathing together', is a unifying theme of this book, so too is its converse: as the Life of Breath project has also shown, at the individual level obstructed or difficult breath is a profoundly isolating and lonely experience.

When the Life of Breath project group welcomed contributors to this book to Durham in 2018 to reflect on and initiate a critical medical humanities account of breath in Western culture, a world so engaged with breath was unthinkable. In our transformed world, it might seem that the rationale for this book is less urgent. If everyone is now talking about breath, can we still assert its absence in our culture and the need to raise awareness about it? In fact people are still not really talking about breath or breathlessness, except in a specific context. Major restrictions on the lives of people around the world may be in place to prevent the spread of COVID-19, yet the focus of attention is not on the symptom of breathlessness itself but rather on ways of preventing the spread of the virus and ways in which lives have changed. Paradoxically, COVID-19 seems to be deflecting attention from the articulation of what breath means, and how we cope with its lack in less extreme, more everyday contexts. Breath and breathlessness are subjects with powerful contemporary resonance, literal and metaphorical. Nevertheless, we do not have adequate terms and conceptions with which to discuss the actual experience of illnesses of the breath.

This theme of invisibility was a key stimulus to the development of the Life of Breath project. ${ }^{34}$ A major aim was to fill a gap in critical writing and awareness of breath and breathlessness in Western thought because the lack of articulation of the meanings and significance of breath can adversely affect those who suffer from breathlessness. Research undertaken by the project emphasised the negative consequences of the difficulty of explaining or expressing breathlessness for those who suffer from it, for societal understanding of it, and for political investment in addressing the growing incidence of lung disease. Findings highlighted the lack of language to express breathlessness, its 'incommunicable' quality, ${ }^{35}$ its isolating effects on sufferers, who experience an absence of social connection and a 'shrinking lifeworld'. ${ }^{36}$ They revealed too the neglect and underfunding of the condition from a research perspective, 
with the result that the mortality rate across the last decade has remained static, by contrast to that for heart disease, which has reduced by $15 \%$, reflecting significant material and scientific investment. ${ }^{37}$ Research benefited from bringing together analysis of lived experience from empirical field work with philosophical phenomenology and literary insights to show that breathlessness is invisible in a complex range of interconnected ways that need to be addressed not just by clinicians but by changes of attitude in politics and society. This change of attitudes requires enhanced awareness and understanding of deep-rooted, culturally driven ideas and assumptions about breath.

The invisibility of breath, then, may be considered in relation to the self, society, and the sphere of policy, where evidence and political will are needed to make real changes for people whose breath is problematic. Individual experience of breathing, like many important bodily functions, occurs largely in the background and is not usually the object of conscious awareness. The philosopher-physician Drew Leder describes these functions as aspects of the 'recessive body', that is, the body outside our conscious influence. ${ }^{38}$ However, unlike other 'recessive' functions, such as the cardiac or gastrointestinal systems, we have some control over breathing. And breathing becomes more conscious as it is taxed by high levels of physical exertion. This provides some experience of breathlessness but, as Havi Carel emphasises, it does not replicate the existential fear of pathological breathlessness: 'it is not like running for a bus; it is not like hiking in high altitude; it's more what I imagine dying is like'. Carel, who herself suffers from chronic breathlessness, speaks of it as expressible only through comparisons such as 'like dying' or 'like drowning'. Breathlessness is 'an overwhelming sensation, to which we are deeply sensitive, but it is also behaviourally subtle, and so often invisible to others'. 39

Breath and breathlessness were brought into focus by the Life of Breath project through co-produced and engaged research activities, externally focussed communications, an exhibition and public events, and hence, the creation of a diverse and unprecedented community, including expertsby-experience, healthcare professionals, artists, and academics from a range of disciplines dedicated to exploring breathing and breathlessness in their own right. A research partnership with British Lung Foundation 'Breathe Easy' support groups for people with respiratory illness both informed the research and led directly into the development of creative writing, singing, and dance programmes which explored the potential 
of the arts to help people live well with breathlessness. These initiatives led in turn to the creation of online resources for breathlessness sufferers, made freely available on the project website and recommended in national health guidance. ${ }^{40}$ Further work addressed the culture of pulmonary rehabilitation, and the barriers presented by clinical settings and language, while collaboration with clinicians built on insights into the cultural formation of experience and the deep connections between breath and embodiment. ${ }^{41}$ This generated new hypotheses concerning the sensation of breathlessness, the cultural contexts that shape the experience of breathlessness, and the problem of symptom discordance.

Central to the project's aim of transforming public understanding of breath and breathlessness was the curation of the public exhibition Catch Your Breath. ${ }^{42}$ The first exhibition ever to focus on breathing and breathlessness, Catch Your Breath drew on the project's research both to raise public awareness and challenge individuals to think differently about a bodily activity often taken for granted. The exhibition (running from November 2018 to February 2020) was hosted by venues academic, medical, and public: Palace Green University Library, Durham, the Royal College of Physicians, London, Southmead Hospital, Bristol, and Bristol Central Library. A smaller version toured libraries and scientific and medical conferences. Each venue attracted different communities and was accompanied by public events ranging from lectures and poetry readings to interactive activities, writing workshops, and mindfulness breathing classes. The exhibition included literary and cultural artefacts from medieval manuscripts to contemporary glass sculptures and short films, and newly commissioned interactive displays exploring the embodied experience of breathing. Through the themes of visibility and invisibility, the exhibition traced historical and cultural connections between breath, body, mind, creativity, and spiritual inspiration. Cultural, religious, and literary conceptions of breath and breathlessness from the classical period to the present were set alongside the medical history of breathlessness, its diagnosis and treatments, the histories of tobacco and air pollution, and the narratives of breathers themselves.

Another focal point of the project's exploration of invisibility was a 'Breath Lab', which brought together those with lived experience of breathlessness, their families and carers, clinicians, and policy-makers to explore the 'language of breathlessness'. ${ }^{43}$ Discussion revealed the difficulty of describing breathlessness. Whereas a wide range of words existed to convey the 'character' of pain, there were few words to characterise 
breathlessness. ${ }^{44}$ The language of breathlessness seemed to have been usurped by the clinical context: the three 'characters' employed by clinicians, 'air hunger', 'the work of breathing' and 'tightness', ${ }^{45}$ left those suffering from breathing illnesses dissatisfied and struggling to find more accurate ways to express their experience. Life of Breath researchers also found that similar linguistic issues render clinical questionnaire tools for assessing the sensory experience of breathlessness confusing and difficult for patients. ${ }^{46}$ Clinical language also inhibited those suffering from breathlessness from taking up opportunities for pulmonary rehabilitation. For the participants in the 'Breath Lab', the inability to find words to describe their experience was not only frustrating but also compounded the invisibility to others that defined their experience. Just as the ability to breathe easily facilitates ordinary social life, so breathing illness inhibits normal social interaction. Those with lived experience of breathlessness described stratagems they adopt to avoid being seen to struggle for breath in public, actions also prompted by the stigma they perceive as associated with their condition on account of its negative connections with smoking, age, and social deprivation. ${ }^{47}$

Language and its lack, the Life of Breath project suggested, are at the heart of the problem of the invisibility of those experiencing breathlessness. The lack of language to express what breathing means, how it feels, and especially what it is like not to be able to breathe, renders understanding opaque for people with breathlessness and for those around them. The inadequacies of the abstract, detached language of the clinic removes agency from those who struggle to breathe and be in the world. Jean-Paul Sartre's characterisation of the nexus of language, body, and the Other captures such disengagement:

Language by revealing to us abstractly the principal structures of our bodyfor-others ... impels us to place our alleged mission wholly in the hands of the Other. We resign ourselves to seeing ourselves through the Other's eyes; this means that we attempt to learn our being through the revelations of language. Thus there appears a whole system of verbal correspondence by which we cause our body to be designated for us as it is for the Other by utilizing these designations to denote our body as it is for us. ${ }^{48}$

Those experiencing breathlessness found it frustrating and shaming, as well as inaccurate, that their experience was articulated only through clinical terms, or the real or imagined disparagement of others. They were 
also seeking ways of articulating this experience that made sense to themselves. For one support group, working with a writer-in-residence at the Catch Your Breath exhibition to produce poetry expressing their experience was revelatory. ${ }^{49}$ They described their 'gratitude' at being offered, through the skill of the writer, metaphors that enabled them to find ways of explaining what breathlessness meant for them:

We have the thoughts.

Mostly hidden.

But words?

Denied, or rather not asked for

Over the millennia.

(From 'A Chance', by Jill Gladstone).

This book explores the language and conceptions that have been used in relation to breath and breathlessness 'over the millennia' from the classical period to the present, and the richness and power of ideas associated with them. It is one step in the larger project of rendering the invisible visible.

\section{The Life of Breath: From Classical to Contemporary}

The imaginative worlds of literature from the classical period onwards demonstrate the complex significance and symbolic power of breath and breathlessness across time, illustrating both cultural shifts and continuities. Breath and breathlessness are flashpoints in a range of discourses, complex terms linked to ideas of health and life and to their converse, illness and death. Breath can signal the most fundamental aspects of human existence-and the most ephemeral.

While breath and breathing have never been such resonant and urgent subjects as they are now, they have not been the subject of systematic cultural or literary study. Studies have focused on particular topics related to breathing - allergy, asthma, the air and pollution, smoking. ${ }^{50}$ This collection, the first of its kind, adopts a wider perspective, tracing the origins and development of ideas concerning breath and breathlessness to explore their imaginative power and to demonstrate how literary texts and the cultural discourses that shape them reflect and reflect upon current ideas, understandings, assumptions, and preconceptions. 
The collection was developed through an invited international conference, which brought together contributors to tease out cultural attitudes and understandings, and to probe the imaginative and affective power of ideas connected with breath across time. Discussion and dialogue were informed by the clinical, sociological, and empirical work of other members of the project team as well as by researchers across a range of literary and cultural disciplines. The volume also draws on The Arts of Breath, a series of public workshop-performances, lectures, and interviews exploring breath in creative arts contexts and forms-poetry, fiction, drama, solo and choral singing, and dance. These events laid the foundations for a volume reflecting the full trajectory of historical ideas of breath and breathlessness, their cultural and creative significance, and their resonances for contemporary understanding and experience.

The book is structured chronologically to present a wide range of cultural reflections within a framework of historical development-classical, medieval, and early modern to the present, with the period from the late sixteenth century to the present represented by some exemplification from each half-century, and over a range of literary, scientific, and cultural discourses, because, with the development of science in every area (but particularly with the chemistry of air, the physiology of breathing, and the more general comprehension and treatment of illness and disease), understandings shifted more quickly in this period. Within this structure contributors trace connections, contrasts, and continuities, with a view also to speaking to current experience of breathing, normal and pathological. The history of breath is not linear: rather, it circles and loops around essential, recurring, often difficult concepts. It is written deeply into religious belief-and into concepts of nature and being. It is inextricable from notions of spirit, inspiration, voice, and movement. It underpins the performing arts-poetry, music, drama, and dance. Its lack-breathlessness - can signal profound emotion but also illness and death. Breath may liberate, but also poison, infect, and contaminate. Breath is longed for, its purity guarded, and its loss feared: synonymous with life and being, it connects body, psyche, and world. While the volume focuses on writing in English and the western cultural discourses that underpin it, individual essays look beyond - to earlier and other literatures and discourses, to other nations and continents, to different epochs and modes of thinking.

The presence and meanings of breath are elicited in a variety of ways. One need not be a Nietzschean to accept in some form the famous proposition of Nietzsche that 'Against positivism, which goes no further 
than the phenomenon and says, "there are only facts", I would say: no, facts are precisely what there are not, only interpretations. We can establish no fact "in itself". 51 The issue with critical medical humanities is where and how to look for interpretations. ${ }^{52}$ Its typical terms for method have anti-methodological implications of unpredictability: entanglement, entwining, imbrication (where the usage has left behind the word's origin in geometric patterning [tiling] to imply interactions of a more free-wheeling kind). Its 'weaving' voices may be on different wavelengths. Its 'dialogic' voices may be speaking at a tangent to each other. In its 'polyphony' dissonances can be passing or unresolved (Palestrina or Ligeti). In its 'heteroglossia' multiple languages may understand each other and communicate, or speak in terms that profoundly complicate if not defy translation and harmonisation (Pentecost or Babel). Binary oppositions are more than superseded: they are extended to a dissolution of boundaries: interdisciplinary becomes 'post-disciplinary'. ${ }^{5}$ The interaction of a range of disciplines-arts and humanities and social science with biomedical science and medical practice-often involves experiments in interpretation, taking the view that nothing has meaning in and of itself but only within some context or mode of understanding which more or less inflects its meanings. While in some modern philosophies of science this is seen as apparent within science itself (Michael Polanyi, Paul Feyerabend, Thomas Kuhn), ${ }^{54}$ the kinds of contextual and cultural interpretations offered by arts and humanities and social science disciplines are characteristically of a different kind. In this collection they are seen, for example, in complexities of history and usage of multivalent words, the complexities of how contexts that inflect interpretation may be assumed, or implied, or change over time, and how meanings arise not only from the reconstructed past and the actual present but also from the accreted history of meanings. As the Romantic-period polymath Friedrich Schlegel puts it, 'every great work, of whatever kind, knows more than it says': ${ }^{55}$ in new contexts works may acquire new meanings, ideas may acquire new applications that were not visible to their author, originator, or earlier interpretive communities.

The volume takes as its starting point classical literature, philosophy, and medical theory from Homer to Galen, which lay the foundations for much later thought, through the Middle Ages and beyond. ${ }^{56}$ Anthony Long demonstrates the long roots of the connections between breath, mind, and body and the startling contemporaneity of ancient ideas concerning breath. Breath and breathing are essential concepts in Platonic 
and Aristotelian philosophy: breath is a fundamental principle of both individual life and the universe. Stoic philosophers took up the notion of pneuma or vital spirit, air and fire, the active generative principle of the universe, which was connected by Galen with the individual physiology of breath and breathing. Late classical philosophy also developed radical ideas of 'conspiration', the subject of Phillip Horky's essay. This notion of the reciprocal breathing of human and divine came to be central not only to classical cosmology but also to early Christian thought. As Thomas Hunt shows, Christian theology drew on both classical concepts of pneuma, the life-giving spirit, and Hebrew notions of ruach, the breath of God, to develop and debate conceptions of the Holy Spirit-conceptions that had political resonances, relating to ideas of order and mastery. From the start, concepts of air, life, spirit, psyche and soul, external and internal pneuma, interweave: blurring into each other, they provoke dynamic responses embedded in changing notions of vitality, consciousness, and power, while the idea of co-breathing resonates with later notions of the interdependence of human and natural worlds.

Medieval medical theory was deeply rooted in classical thought and its Arabic reworkings, invoking the notion of the vital spirits to explain the physiology of the emotions and the intersection of thought with feeling. Corinne Saunders explores how the interrelated ideas of breath and vital spirits underpin and shape representations of affective experience in medieval imaginative texts, from popular romances to the medically alert fictions of Chaucer, arguing that representations that may seem to modern readers purely conventional are rooted in the medieval physiology of the breath. A similar understanding of the apparently conventional as physiological can also be seen, she argues, in devotional and visionary works, in which the concepts of vital spirits and the Holy Spirit intersect, giving breath a peculiar force. The Book of Margery Kempe offers an extended narrative of these intersections of physical and spiritual in Kempe's deeply embodied piety. Medieval physiological models provide a context and framework for Kempe's experience allowing the reader to place it not simply as performative or conventional but as rooted in learned ideas that were passing into general currency. The play of breath in tears, sighs, and swoons writes feeling on the body, creating a living tapestry of emotional experience from romantic love to mystical vision. Denis Renevey explores the possibility that medieval mystical experience was in part rooted in 'volitional breathing' resulting in changes to consciousness, drawing, in the absence of evidence in mystical texts 
themselves, on the insights of professional brass-players, eastern spiritual practices and the breathing techniques of 'new age' therapies. The repetition of prayers such as that on the Name of Jesus, he suggests, may have allowed for the conscious manipulation of the deep connection between breath and consciousness. At the same time, as Carole Rawcliffe shows, consciousness of the dangers of breathing infected air manifested itself in actions designed to improve air quality in medieval cities in a period repeatedly threatened by plague and epidemic. Being in the world depended not only on the movement of the bodily spirits but also on the purity of the air breathed in to form the vital spirits and influence the health of mind and body.

In turning from the medieval period to the early modern, the collection explores how, over the following centuries, these notions endured but took on new forms as understandings of physiology, disease, and the spiritual changed and developed. Katherine Craik and Stephen Chapman offer a novel perspective on present-day breathlessness by considering this within the unfamiliar context of early modern literature and culture. They argue that cross-disciplinary study can work not only by applying disciplines of interpretation from the arts and humanities to medicine but also in the other direction: medical science can shed new light on Shakespeare. As they demonstrate in relation to King Lear, early modern writing took up traditions of thought in which there was no simple separation between physiology and metaphysics. Breath — and its loss-define individual identity, but also human relationality, presaging the ways that breathlessness shapes not only its sufferers but also those who 'con-spire' with and care for them. Breath, fundamental to life, connecting mind and body, opens onto profound-and timeless - ethical questions. The early modern period retained the connection of breath with devotion and spiritual inspiration, enacted and sought after in highly physical affective encounters; it also extended physiological and psychological theories concerning the emotions. Naya Tsentourou revisits treatises on the passions to elucidate the place of breath within the early modern history of emotion, with a particular focus on the sigh, a response signalling overwhelming emotion that deregulates and disrupts. Science and art, thinking and feeling, form and meaning, intersect and clash as writers engage with the disruptive emotional valences of breath. Intertextual references to emotional breathing blur the distinction between patient and physician: bodies and texts become spaces where the detached witness conspires with the lovesick subject, and in turn, with the reader. Early Christian debate 
concerning the relations between breath, soul, and the Holy Spirit was reanimated in the political context of questions of the divine right of kings, exploited, as Patrick Gray shows, by John Donne in his sermon on a text from the Lamentations of Jeremiah, 'the breath of our nostrils'. Here, through Donne's complex play with Hebrew terms signifying life, spirit, and soul, breath becomes deeply ambiguous, its valences dependent on both political and religious interpretation.

Eighteenth-century medical and scientific discoveries complicated long-standing ideas of the connection between interior and exterior, individual and environment through new understandings of the nature of air and debates surrounding its potential role in disease. Rina Knoeff probes the medical, cultural, and imaginative effects of these, which were taken up in theories of pathology and environment, leading to new emphases on the importance of exercise, clean air, and landscape, both interior and exterior, and shaping artistic consumption. Ideas connecting breath with well-being were closely allied to understandings of embodied emotional experience. Gillian Skinner explores the formative role of breath and breathlessness in eighteenth-century notions of sensibility, in particular feminine sensibility, and in the literary genre of sentimental fiction these inspired. Again, images of sudden loss of breath-fainting and swooning-recur, brought out with peculiar force in Frances Burney's epistolary novel Evelina where the writing of emotion on the body and on the page intersect. Attention to the breath reveals a proto-feminist heroine, actively involved in scenarios that both challenge her capacity for moral conduct and demonstrate her power to act. At the same time, there were threats related to breathlessness, including, as Andrew Russell shows, through the introduction of a new and powerful material agent, tobacco, a primary cause of breathing illnesses worldwide, with profound and enduring effects on health and medicine. Adding smoke to breath instituted a culture fuelled by the perceived intellectual and creative possibilities of tobacco. Russell argues that the arrival in Europe of tobacco, with its ability to change processes of cognition, influenced literary developments, including the 'poetry of attention', with its interest in minute detail, and the distinctive 'it'-narratives of the period, which emphasise the division between self and other. In tobacco, with its apparent offer of inspiration from heightened experience, promise and danger combined.

Cultural and literary conceptions of breath were similarly dualistic- on the one hand, opening onto the sublime, and on the other, signalling human frailty. The concept of divine, life-giving breath retained its 
connections with Christianity, as in the familiar Victorian hymn, 'Breathe on me, breath of God', but was also extended. Romantic writers developed a theory of inspired composition rooted in nature rather than the supernatural, with the metaphor of a 'correspondent breeze', a quasi-divine breath whose power operates through the poet. As Clark Lawlor shows, such notions of inspiration were both shadowed and enhanced by the threat of the loss of breath and the fading out of vitality through illness, in particular, the Romantic disease of tuberculosis, more commonly known as 'consumption' owing to its effects on the body. Consumption was 'fashionable', a disease that in the popular imagination illuminated the spirit as the body wasted, and which became a powerful artistic and literary topos, while in reality mortality was marked all too acutely on the consumptive breath. In Romantic constructions of consumption, ancient connections of breath with death, life, spirit and genius take on new force, heightened by the experience of breathlessness.

Nineteenth-century writers sustained such images of consumption, with their complex interweaving of respiratory difficulty with intensity of life. The industrial revolution also brought a new interest in the possibility that disease could be carried by air and inhaled, and in new subjects connected with breath and illness: emphysema and other diseases caused by, for example, cotton processing and mining. Victorian engagement with breath in relation to industrial shifts was marked by duality. Progress could seem to signal movement towards immortality, as Francis O'Gorman demonstrates in relation to the invention of the mechanically powered pipe organ - an instrument with seemingly endless breath, which inspired new literary engagements with the eternal. Yet the contrast with limited human breath also signalled the frailty of human life, the limits of possibility and the inevitability of death. A similar duality characterised the ways that the nineteenth century engaged with the effects of industrialisation on the natural environment, which had severe negative consequences for breathing, most marked in the phenomenon of London fog. Christine Corton explores how, in literature and culture, this densely polluted air came to be represented as food, a soup that was inhaled and ingested-a metaphor that paradoxically appeared to celebrate this aspect of London, perhaps delaying legislation for clean air, even as fog's breath-damaging qualities were acutely recognised by Victorian medicine, as contemporary records and reports connecting high mortality rates with dense fogs demonstrate. The intersection of ideas of poison and nutrition offered rich and enduring creative possibilities for both writers and 
artists. Alongside this emphasis on the relation between air and illness, at the fin de siècle, as Fraser Riddell shows, new sexological discourses placed the breathing body centre stage. In both aesthetic theory and poetry, the ideas of consumptive wasting, lung disease, and air that kills came together to shape queer notions of embodiment that highlighted forbidden but all-consuming and inspiring experiences of materiality, loss, and desire. Breath and breathlessness animated treatments of the homosexual subject.

Modernism acted as a crucible for ideas of breath and breathlessness. Within a context of dramatic scientific, intellectual, cultural, and aesthetic shifts, new forms of writing emerged to which breath was central in radically different ways. The notion of divine, life-giving breath was questioned and complicated in a world where religious faith was profoundly challenged. New developments in medicine and psychoanalysis extended and altered understandings of body, mind, and affect, and their connections. As Arthur Rose and Oriana Walker argue, breath played a complex role in psychoanalysis from the late nineteenth century to the 1930s, as a potential signifier of psychic experience, and as a psycho-physical variable in its own right for the theorists who followed and challenged the founders of the discipline. Breath becomes an 'uncanny object' and a key to the unconscious: it also continues as a focus for debates concerning vitality, materiality, spirit, and consciousness. Breath and its politics illuminate in new ways the histories of psychoanalysis and psychotherapy. At the same time, changes in relation to the lived environment led to new ideas of breathing in the world. Abbie Garrington explores the encounter of science, culture, and art in modernist attitudes to mountaineering, an activity that tested the limits and possibilities of breath, engaging with deeply ingrained ideals of masculinity and bodily endurance. New developments in the oxygen rig, like the Victorian invention of the mechanical organ, promised more enduring breath, yet also pointed to man's limits on the mountains, challenging ideas of heroism. Such possibilities and paradoxes contributed to the new poetic breath of modernism, as did new questions concerning the relation of mind and body. Taking up William James's idea of 'consciousness-as-breath', Marco Bernini probes Samuel Beckett's interweaving of physiology and psychology in representations across his oeuvre of breath as intimately bound up with mind, revealing the workings and textures of consciousness and prefiguring more recent ideas of embodied cognition. 
The long-standing connection between breath and inspiration was newly rewritten not only in European thought but also by American poets from Walt Whitman to the Black Mountain School, who located the formal and rhetorical structures of poetry in the rhythms of breathing. David Fuller takes up the subject of breath in poetry and aesthetic theory in America with a particular focus on Charles Olson's concept of the breath-line and the related experiments with poetic form of William Carlos Williams, setting these experiments alongside those of the German poet Paul Celan, whose poetry and poetics of difficulty enact a 'breathturn', a profound change of direction, a new beginning, in response to the chilling questions for art raised by the cataclysm of World War II. The poetry of breath is necessarily embodied, intimately connected with the voice, a topic Fuller also addresses through consideration of the implications of and need for reading poetry aloud. Twenty-first-century poetics, as Stefanie Heine shows, has returned to the 'pneumatic turn' of the 1950s and 1960s. The contemporary African American writer M. NourbeSe Philip develops from Olson her own ideas of respirational poetics, beginning from the ethically positive idea of pre-natal 'conspiration', a mother breathing for her unborn child. Heine elaborates Philip's exemplification of a poetics of fragmentation in her anti-narrative narrative poem, Zong!, which engages with and radically remakes Olson's interests in the syllable and in word-materials taken over from a problematic 'mother-text', a case report related to a massacre of African captives thrown overboard from a slave-trading ship in the late eighteenth century in order to collect insurance on the 'cargo'. Philip's 'conspiration' is also a deconstruction of language, speaking to the violent silencing of the voices which Zong! evokes and to conspiration/conspiracy against black lives.

Modern technology has yielded new possibilities of realising breath in art. The contemporary visual artist Jayne Wilton has drawn on the possibilities offered by modern technology to examine the relationship between breather and spectator, individual and environment. Her work translates breathing into art, rendering the unseen visible-an extraordinary moment in the long history of the art of breath and breathlessness, which reaches back to primitive art and is refigured across cultural epochs. Wilton's work engages directly with sufferers from breathlessness, a refiguring of conspiration that challenges comfortable assumptions but also shows the potential of the arts to articulate embodied experience. The potential unease and violence of conspiration are presented in a radical new light by the contemporary English poet Michael Symmons Roberts, 
whose novel Breath (2006) explores a lung transplant that also becomes a deeply political act within a context of civil war. Breath opens onto questions of the intersection of mind and body, identity and consciousness, spirit and voice. These issues emerge across Symmons Roberts' writing, which is also concerned with how the poet, poem, and reader may realise structures of breathing implied by the printed page. In the arts of breath, frailty and resilience meet.

As Peter Adey shows in his Afterword, across the book themes and issues interweave: the body and pathology, vitality and emotion, soul and spirit, inspiration and creation, conspiration and community, politics and environment, nature and technology, voice and silence, and, above all, identity and consciousness. He also returns to the contexts in which the book was completed of an international breathing illness pandemic and the Black Lives Matter movement. As he suggests, the movements, meanings, vocalisations, and violences of breath are among the defining moments of our time. Lives, beings, and imaginings are inextricably bound up-for better or worse-with breathing in the world. From the ancient world to the present, philosophy, literature, and the cultures they reflect and shape write the life of breath.

\section{Notes}

1. 'The Age of the Breath', Luce Irigaray: Key Writings, ed. by Luce Irigaray (London: Continuum, 2004); Part IV: Spirituality and Religion, 165-70.

2. Luce Irigaray, The Forgetting of Air in Martin Heidegger (1983), trans. by Mary Beth Mader (Austin: University of Texas Press, 1999). For the variety of areas into which Irigaray's fundamental argument can be extended, including religion, politics, and animal and environmental ethics, see Lenart Škof and Emily A. Holmes (eds), Breathing with Luce Irigaray (London: Bloomsbury, 2013), which includes a new essay by Irigaray herself, 'To begin with breathing anew'. For a further extension see Anne Emmanuelle Berger, 'Irigaray's Breath, or Poetry after Poetics', in Philosophy and Poetry: Continental Perspectives, ed. by Ranjan Ghosh (New York: Columbia University Press, 2019), 209-34. For recent developments of Irigaray's views on the centrality of air and breathing, the crucial importance of human relations with the natural environment, and implications of this for animal and environmental ethics, see Luce Irigaray and Michael Marder, Through Vegetal Being: Two Philosophical Perspectives (New York: Columbia University Press, 2017). 
3. On the contrary, even within the area of their primary application, to feminism, Irigaray's claims have been radically contested as 'essentialist', mistaking cultural constructions of gender for conditions of nature. See, for example, Judith Butler, Gender Trouble: Feminism and the Subversion of Identity (London: Routledge, 1990; 2nd edn, 2006).

4. Peter Sloterdijk, Terror from the Air, trans. by Amy Patton and Steve Corcoran (Los Angeles, CA: Semiotext(e), 2009). For a compressed but very well documented extension and complication of Sloterdijk's argument about 'atmo-terrorism', showing how knowledge of air's relationship to breathing has informed not only twenty- and twenty-first-century military technology but also processes of governance ('atmospheric policing'); see Marijn Nieuwenhuis, 'The Politics of Breathing: Knowledge on Air and Respiration', in Atmospheres of Breathing, ed. by Lenart Škof and Petri Berndtson (New York: SUNY, 2018), 199-218.

5. That Sloterdijk implicitly dissents from Irigaray's view of Heidegger as 'forgetting air' (Terror, 60-63) hardly affects their confluence of focus. (Sloterdijk interprets Heidegger's later discourse of Heimatlosigkeit [homelessness] as related to the profound change in the environment of air that is Sloterdijk's subject: air transformed from life-giving to death-dealing.).

6. Antonin Artaud, The Theatre and its Double (1964; essays ca. 19321938), trans. by Victor Corti (Richmond: Oneworld Classics, 2010); quotation from 'An Affective Athleticism', 93-99 (99). For a reading of Artaud that foregrounds the issue of breath see Jacques Derrida, 'La Parole Soufflée', Writing and Difference (Chicago: University of Chicago Press, 1978), and the discussion of this by Jones Irwin, 'Theater of Breath', in Atmospheres of Breathing, ed. by Škof and Berndtson, 167-78.

7. On the presence of breath in modern and contemporary poetry, see the essays in this collection by Fuller and Heine, and the interview with Michael Symmons Roberts.

8. Sozita Goudouna, Beckett's 'Breath': Anti-theatricality and the Visual Arts (Edinburgh: Edinburgh University Press, 2018). Central figures of Goudouna's account include happening, performance, and conceptual artists, Marcel Duchamp (1887-1968), Joseph Beuys (1921-1986), and Piero Manzoni (1933-1963), but also artists working in more traditional modes, Bram van Velde (1895-1981), and the video-artist Bill Viola (b. 1950). On breathing in visual art, ancient to contemporary, see the essay in this collection by Jayne Wilton.

9. Jacques Lacan, Anxiety: The Seminar of Jacques Lacan. Book X, ed. by Jacques-Alain Miller, trans. by A. R. Price (Cambridge: Polity, 2015).

10. Anxiety, 298-99. For the background treated allusively by Lacan (speculations of the Church Fathers on the fecundating divine breath) see 
Leo Steinberg, "'How shall this be?" Reflections on Filippo Lippi's Annunciation', Artibus et Historiae, 1987 (8), 25-44.

11. L. O. Aranye Fradenburg, Staying Alive: A Survival Manual for the Liberal Arts, ed. by Eileen O. Joy (New York: Punctum, 2013); especially ch. 3, 'Breathing with Lacan's Seminar X: Expression and Emergence', and the response of Ruth Evans, 'Fugue 3: The Object Breath'.

12. Škof and Berndtson (eds), Atmospheres of Breathing: see Note 4.

13. See Note 6 (Irwin, 'Theater of Breath').

14. Havi Carel, 'Invisible Suffering: The Experience of Breathlessness', in Atmospheres of Breathing, ed. by Škof and Berndtson, 233-45. (Professor Carel was the leader of the Bristol team for the Life of Breath project.).

15. These have been more or less adapted or transformed in various contemporary Western practices. For recent examples, see Robin Rothenburg, Restoring Prana: A Therapeutic Guide to Pranayama and Healing through the Breath for Yoga Therapists, Yoga Teachers, and Healthcare Practitioners (London: Jessica Kingsley, 2019); and James Nestor, Breath: The New Science of a Lost Art (London: Penguin, 2020).

16. Luce Irigaray, Between East and West: From Singularity to Community, trans. by Stephen Pluhácek (New York: Columbia University Press, 2003).

17. As with Irigaray's arguments about gender seen as 'essentialist' (see Note 3 ), her views on Eastern religions have been subject to critique as 'orientalist' (based in uncritically Western views of Eastern cultures): see Morny Joy, Divine Love: Luce Irigaray, Women, Gender and Religion (Manchester: Manchester University Press, 2006), especially ch. 6, 'Irigaray's Eastern Excursion'.

18. See the essays in this collection by Long, Horky, Hunt, and Gray.

19. See the essay in this collection by Renevey.

20. See George G. Ganss, SJ, The Spiritual Exercises of Saint Ignatius: A Translation and Commentary (St Louis, MI: Institute of Jesuit Sources, 1992), \$258. Ignatius began the Spiritual Exercises in 1521 and completed the final substantive version in 1541. A plausible estimate (Ganss, 8) suggests the work has been through over 4,500 editions worldwide.

21. 'The Way of a Pilgrim'; and 'The Pilgrim Continues his Way', trans. by R. M. French (1931; 1943; London: SPCK, 1954), 54. The method of breathing recommended here (an in-breath for the first half of the prayer, an out-breath for the second half) is just one of various suggested methods: see Per-Olof Sjögren, The Jesus Prayer (1966), trans. by Sydney Linton (1975; 3rd edn, London: SPCK, 1996), 41-45. See also the interview in this collection with Michael Symmons Roberts.

22. The Philokalia: The Complete Text, ed. and trans. by G. E. H. Palmer, et al., 4 vols (London: Faber, 1979-95); quotation, vol. 4, 66; and see, 
for example, St Gregory Palamas, 'In Defence of Those Who Devoutly Practice a Life of Stillness', vol. $4, \$$ 7.

23. Ashon T. Crawley, Blackpentecostal Breath: The Aesthetics of Possibility (New York: Fordham University Press, 2017).

24. Crawley, Blackpentecostal Breath, 44-47. The 'scientific' account to which Crawley refers is taken from Yutaka Haruki, et al. (eds), Respiration and Emotion (New York: Springer, 2001).

25. For further discussion of the Black Lives Matter movement in this collection, see Peter Adey's extended 'Afterword'. See also the essay by Stefanie Heine, which discusses M. NourbeSe Philip's Zong!, based on a slave ship massacre and its legal consequences central to the eventual abolition of the slave trade in Britain and the British Empire.

26. Achille Mbembe, 'The Universal Right to Breathe', trans. by Carolyn Shread, Critical Inquiry, Posts from the Pandemic, 13 April 2020: https://critinq.wordpress.com/2020/04/13/the-universal-rightto-breathe/.

27. For elaboration and development of these arguments, see Jane Macnaughton, 'Medical Humanities' Challenge to Medicine', Journal of Evaluation in Clinical Practice 17 (2011), 927-32, and William Viney, Felicity Callard, and Angela Woods, 'Critical Medical Humanities: Embracing Entanglement, Taking Risks', Medical Humanities 4l (2015), 2-7.

28. For a particular example of this approach, see Alice Malpass, et al., 'Disrupted Breath, Songlines of Breathlessness: An Interdisciplinary Response', Medical Humanities 45/3 (2019), 294-304.

29. World Health Organisation, 'The Top 10 Causes of Death', 2016, https://www.who.int/news-room/fact-sheets/detail/the-top-10causes-of-death.

30. British Lung Foundation (BLF), Invisible Lives: Chronic Obstructive Pulmonary Disease (COPD)—Finding the Missing Millions (London: BLF, 2007).

31. British Lung Foundation, The Battle for Breath: The Impact of Lung Disease in the UK (London: BLF, 2016), 5: https://www.blf.org.uk/ policy/the-battle-for-breath-2016.

32. Figures from national public health agencies as collected by Johns Hopkins University: https://coronavirus.jhu.edu/map.html [last consulted: 27 February 2021].

33. Michael Marmot, et al., Build Back Fairer: The COVID-19 Marmot Review. The Pandemic, Socioeconomic and Health Inequalities in England (London: Institute of Health Equity, 2020).

34. Jane Macnaughton, 'Making Breath Visible: Reflections on Relations between Bodies, Breath and World in the Critical Medical Humanities', Body and Society 26/2 (2020), 30-54. 
35. Havi Carel, Phenomenology of Illness (Oxford: Oxford University Press, 2016), 121.

36. Rebecca Oxley and Jane Macnaughton, 'Inspiring Change: Humanities and Social Science Insights into the Experience and Management of Breathlessness', Current Opinion in Supportive Palliative Care 10/1 (2016), 256-61 (259).

37. BLF, The Battle for Breath, 4.

38. Drew Leder, The Absent Body (Chicago: University of Chicago Press, 1990), 53.

39. Carel, Phenomenology of Illness, 110, 109.

40. Resources include downloadable breathing exercises, dance class videos, a podcast series, and multiple blog posts, all of which can be found via the project website: https://lifeofbreath.org/. They are recommended in lists of patient resources created by (among others) the UK National Institute for Health Research, the British Thoracic Society, and Lung Foundation Australia. Cf. the initiative recently launched by the singer Renée Fleming, Healing Breath: breathing exercises for bealth and wellbeing: https://artsandculture.google.com/project/healing-breath.

41. Jane Macnaughton, et al., 'Chronic Breathlessness: Rethinking the Symptom', European Respiratory Journal 51 (2018), 1702331.

42. On the exhibition and associated events, with an extensive series of related blogs and an online version of the exhibition by its curator, David Wright, see: https://catchyourbreath.org/. Two clinical fellows of the Royal College of Physicians, Nigel Cook and Noel Snell, created an accompanying booklet, Breath and Breathing: An In-depth Look at the Processes Involved in Breathing, and the Difficulties Faced by Sufferers of Breathlessness, available on the exhibition website.

43. Rebecca Oxley, et al., "The Meaning of the Name of "Pulmonary Rehabilitation" and Its Influence on Engagement with Individuals with Chronic Lung Disease', Chronic Respiratory Disease 16 (2019), 1-9.

44. Macnaughton, 'Making Breath Visible', 40.

45. Robert W. Lansing, Richard H. Gracely, and Robert B. Banzett, 'The Multiple Dimensions of Dyspnea: Review and Hypothesis', Respiratory Physiology and Neurobiology 167/1 (2009), 53-60.

46. Alice Malpass, Coreen McGuire, and Jane Macnaughton, "“The Body Says It": The Difficulty of Measuring and Communicating Sensations of Breathlessness', Medical Humanities (Epub ahead of print: 28 January 2021), 0:1-13. doi:10.1136/medhum-2019-011816.

47. Macnaughton, 'Making Breath Visible', 36.

48. Jean-Paul Sartre, Being and Nothingness: An Essay on Phenomenological Ontology, trans. by Hazel E. Barnes (1958; London: Routledge, 2003), 377. 
49. See https://catchyourbreath.org/the-secret-to-breathe/ which shows and describes the work of the project's writer-in-residence, Christy Ducker; on her workshops see https://catchyourbreath.org/sharing-theunshareable/.

50. Gregg Mitman, Breathing Space: How Allergies Shape our Lives and Landscapes (New Haven, CT: Yale University Press, 2008); Mark Jackson, Asthma: The Biography (Oxford: Oxford University Press, 2009); Steven Connor, The Matter of Air: Science and the Art of the Ethereal (London: Reaktion Books, 2010); Virginia Berridge, Demons: Our Changing Attitudes to Alcohol, Tobacco, and Drugs (Oxford: Oxford University Press, 2013).

51. The Will to Power (1901; rev. edn 1906) [a compilation from Nietzsche's Notebooks overseen by his sister], trans. by R. Kevin Hill and Michael A. Scarpitti (London: Penguin, 2017), 287. For the German text in its original notebook form see Nietzsche, Werke, VIII.1, Nachgelassene Fragmente. Herbst 1885 bis Herbst 1887 (Berlin: de Gruyter, 1974), 7 [60], 323.

52. For the history and current state of this developing discipline, see the introduction to The Edinburgh Companion to the Critical Medical Humanities, ed. by Anne Whitehead, Angela Woods, et al. (Edinburgh: Edinburgh University Press, 2016), 1-31.

53. On interdisciplinary studies and the 'post-disciplinary' implications of their methodological variety, see David Fuller, "'There is no method ..."? Contact and Conflict in Interdisciplinary Studies', Contact and Conflict in English Studies, ed. by Sabine Coelsch-Foisner and Herbert Schendl (Frankfurt: Peter Lang, 2015), 133-49.

54. Michael Polanyi, Personal Knowledge: Towards a Post-critical Philosophy (London: Routledge, 1958); Paul Feyerabend, Against Method: Outline of an Anarchistic Theory of Knowledge (1975), 3rd edn (London: Verso, 1993); Thomas S. Kuhn, The Structure of Scientific Revolutions (1962), 3rd edn (Chicago: Chicago University Press, 1996).

55. 'On Goethe's Meister', in Classic and Romantic German Aesthetics, ed. by J. M. Bernstein, Cambridge Texts in the History of Philosophy (Cambridge: Cambridge University Press, 2003), 269-86 (281). For the German text see Friedrich Schlegel, Kritische Nenausgabe, ed. by Ernst Behler, et al., 35 vols (Munich: Schöningh, 1958-2006), II. Charakteristiken und Kritiken I (1796-1801), ed. by Hans Eichner, 1967, 126-46 (140).

56. For historical understandings of the physiology of breathing, see the essays on the classical period by Long, on the medieval period by Saunders, and by Knoeff on the eighteenth century before Lavoisier, whose experiments on human and animal breathing initiated a revolution in the understanding of respiratory physiology. The ideas are set in historical 
conspectus, with an idiosyncratic emphasis on the work of John Mayow (1641-79), in Donald F. Proctor (ed.), A History of Breathing Physiology (New York: Marcel Dekker, 1995). For an alternative account of Mayow and other mid-seventheenth-century developments, see Robert G. Frank, Harvey and the Oxford Physiologists: Scientific Ideas and Social Interactions (Berkeley: University of California Press, 1980).

\section{Selected Bibliography}

Boston, Jane, and Rena Cook, eds 2009. Breath in Action: The Art of Breath in Vocal and Holistic Practice. London: Jessica Kingsley.

Connor, Steven. 2010. The Matter of Air: Science and Art of the Ethereal. London: Reaktion.

Crawley, Ashon T. 2017. Blackpentecostal Breath: The Aesthetics of Possibility. New York: Fordham University Press.

Fradenburg, L. O. Aranye. 2013. Staying Alive: A Survival Manual for the Liberal Arts. Ed. Eileen O. Joy. New York: Punctum.

Goudouna, Sozita. 2018. Beckett's 'Breath': Anti-theatricality and the Visual Arts. Edinburgh: Edinburgh University Press.

Irigaray, Luce. 1999. The Forgetting of Air in Martin Heidegger (1983). Trans. Mary Beth Mader. Austin: University of Texas Press.

- ed. 2004. Luce Irigaray: Key Writings. London: Continuum.

Irigaray, Luce, and Michael Marder. 2016. Through Vegetal Being: Two Philosophical Perspectives. Chicago: Chicago University Press.

Shusterman, Richard. 2008. Body Consciousness: A Philosophy of Mindfulness and Somaesthetics. Cambridge: Cambridge University Press.

Škof, Lenart, and Petri Berndtson, eds 2018. Atmospheres of Breathing. New York: SUNY.

Škof, Lenart, and Emily A. Holmes, eds 2013. Breathing with Luce Irigaray. London: Bloomsbury.

Sloterdijk, Peter. 2009. Terror from the Air. Trans. Amy Patton and Steve Corcoran. Los Angeles, CA: Semiotext(e).

Whitehead, Anne, Angela Woods, et al., eds 2016. The Edinburgh Companion to the Critical Medical Humanities. Edinburgh: Edinburgh University Press. 
Open Access This chapter is licensed under the terms of the Creative Commons Attribution 4.0 International License (http://creativecommons.org/licenses/ by $/ 4.0 /$ ), which permits use, sharing, adaptation, distribution and reproduction in any medium or format, as long as you give appropriate credit to the original author(s) and the source, provide a link to the Creative Commons license and indicate if changes were made.

The images or other third party material in this chapter are included in the chapter's Creative Commons license, unless indicated otherwise in a credit line to the material. If material is not included in the chapter's Creative Commons license and your intended use is not permitted by statutory regulation or exceeds the permitted use, you will need to obtain permission directly from the copyright holder.

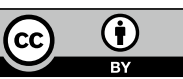

